\title{
From despair to hope: copying of relatives of hospitalized children before bad news report
}

\author{
Do desespero à esperança: enfrentamento de familiares de crianças hospitalizadas diante de notícias difíceis \\ De desesperado a esperanza: enfrentamiento de los miembros de la familia de ninos hospitalizadosantes de noticias dificiles
}

Luciana Palacio Fernandes Cabeça' ORCID: 0000-0001-9150-6135

Luciana de Lione Melo' ORCID: 0000-0002-6730-9075

'Universidade Estadual de Campinas. Campinas, São Paulo, Brazil.

How to cite this article:

Cabeça LPF, Melo LL. From despair to hope: copying of relatives of hospitalized children before bad news report. Rev Bras Enferm. 2020;73(Suppl 5):e20200340. doi: http://dx.doi.org/10.1590/0034-7167-2020-0340

\section{Corresponding author:}

Luciana Palacio Fernandes Cabeça

E-mail: cabeclp@gmail.com

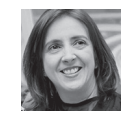

EDITOR IN CHIEF: Antonio José de Almeida Filho ASSOCIATE EDITOR: Ana Fátima Fernandes

Submission: 05-28-2020

Approval: 08-24-2020

\section{ABSTRACT}

Objective: to understand the experiences of relatives of critically ill children before bad news report. Method: a phenomenological study based on Heidegger's philosophical framework. Data collection was carried out from October 2018 to March 2019, through phenomenological interviews with 15 relatives of children hospitalized in a Pediatric Intensive Care Unit. Results: relatives, in their existentiality, experience the facticity thrown into unpredictable situations, regardless of their choices and are faced with feelings of shock, despair and fear before bad news. After emotional impact, especially regarding the possibility of death, relatives reveal hope as a mechanism for coping with the situation. Final considerations: solidarity and sensitivity by health professionals, especially nurses, are essential in understanding the existential dimension of relatives who experience such an experience, understanding the several facets of their existence and offering them opportunities to project themselves. Descriptors: Communication; Hope; Relatives; Child, Hospitalized; Qualitative Research.

\section{RESUMO}

Objetivo: compreender as vivências de familiares de crianças gravemente doentes diante da comunicação de notícias difíceis. Método: estudo fenomenológico, fundamentado no referencial filosófico de Heidegger. A coleta de dados foi realizada no período de outubro de 2018 a março de 2019, por meio de entrevistas fenomenológicas com 15 familiares de crianças hospitalizadas em Unidade de Terapia Intensiva Pediátrica. Resultados: os familiares, em sua existencialidade, vivenciam a facticidade lançados em situações imprevisíveis, independente de suas escolhas, e se deparam com sentimentos de choque, desespero e medo diante das notícias difíceis. Após o impacto emocional, principalmente quanto à possibilidade de morte, os familiares revelam esperança como mecanismo para o enfrentamento da situação. Considerações finais: acredita-se ser imprescindível a solidariedade e a sensibilidade dos profissionais de saúde, em especial de enfermagem, na apreensão da dimensão existencial do familiar que vivencia tal experiência, compreendendo as múltiplas facetas de seu existir, oferecendo-lhes oportunidades para projetar-se.

Descritores: Comunicação; Esperança de Vida; Familiares; Criança Hospitalizada; Pesquisa Qualitativa.

\section{RESUMEN}

Objetivo: comprender las vivencias de familiares de niños críticamente enfermos al comunicar noticias difíciles. Método: estudio fenomenológico, basado en el marco filosófico de Heidegger. La recolección de datos se realizó desde octubre de 2018 a marzo de 2019, mediante entrevistas fenomenológicas a 15 familiares de niños hospitalizados en una Unidad de Cuidados Intensivos Pediátricos. Resultados: Ios familiares, en su existencialidad, experimentan la facticidad arrojados a situaciones impredecibles, independientemente de sus elecciones, y se enfrentan a sentimientos de conmoción, desesperación y miedo ante una noticia difícil. Tras el impacto emocional, especialmente en cuanto a la posibilidad de muerte, los familiares revelan la esperanza como mecanismo para afrontar la situación. Consideraciones finales: se cree que la solidaridad y sensibilidad de los profesionales de la salud, especialmente enfermeras, es fundamental para aprehender la dimensión existencial del familiar que vive tal experiencia, entendiendo las múltiples facetas de su existencia, brindándole oportunidades para proyectarse.

Descriptores: Comunicación; Esperanza de Vida; Familia; Niño Hospitalizado; Investigación Cualitativa. 


\section{INTRODUCTION}

In Pediatric Intensive Care Units (pediatric ICUs), it is common for relatives to be approached by health professionals with bad news information ${ }^{(1)}$. In terms of health care, bad news is considered to be "any information that produces a change in the person's perspectives on his present and future"; are constantly associated with situations of loss and/or any information that is not welcome ${ }^{(2)}$.

Serious health conditions can have a significant impact on the family, such as suspicious diagnoses, failure of curative therapies, need for fathernful and/or uncomfortable procedures, surgical procedure indications, prolonged hospitalizations, reserved prognosis and/or issues about end-of-life care indication ${ }^{(3)}$.

Studies show that the quality of how bad news is announced has an impact on the recipient, especially with psychosocial repercussions ${ }^{(4)}$. Each family has its particularities, bringing with them stories, habits, beliefs, experiences, culture and educational process, and may present distorted and generalized interpretations of what is transmitted to them as information. The capacity for immediate understanding of those who receive them may be limited, preventing the understanding of the explanations and guidelines conveyed by professionals ${ }^{(5-7)}$.

In this context, when reporting this news, relatives will be able to react in different ways, in different ways and configurations, covering a variety of situations ${ }^{(8)}$; expressions of shock, fear, despair, sadness, isolation and fathern are more frequent ${ }^{(1,9-11)}$. Faced with the impossibility of changing the situation, they feel dissatisfied and dissatisfied, as well as concerned about future prospects ${ }^{(12)}$, especially when it refers to the possibility of losing their children ${ }^{(13-14)}$.

However, after the initial impact, relatives seek to understand the steps necessary to continue their trajectories so that, in the midst of obstacles, hope has taken place, providing balance to cope with the situation, improving mood when everything seems distressing ${ }^{(15-16)}$.

Based on the above, the question was: what are the experiences of relatives of children hospitalized in a Pediatric Intensive Care Unit before bad news report? Therefore, it is believed that knowing how relatives cope before bad news experiences can contribute substantially to individualize care and improve communication between health team and family.

\section{OBJECTIVE}

To understand the experiences of relatives of critically ill children before bad news report.

\section{Theoretical-philosophical framework}

As a theoretical-philosophical framework, some of the essential concepts of Martin Heidegger's work, Being and Time, were adopted, which considers, in his analyzes, the world as a historical horizon of meanings in a way that the world that makes it possible for something to show itself by phenomenological experience ${ }^{(17)}$.

Heidegger points to understanding the existence of being in ontological sense, as it turns to the very question of being of entity, in different modalities. It is concerned with clarifying and substantiating the way in which it is possible to ask not only "what" is man as a living being, but, above all, "who" and "how" he is, what determines an entity as an entity ${ }^{(17-18)}$.

To understand Heidegger's thinking, one must understand entity and being from his perspective. Entity is "everything we talk about, what we aim at, in relation to what we behave in this and that way; entity is also what we are and how we are ourselves"(17). Being is not a categorical statement, nor an entity and no concept obtained by deduction, but the presence, the manifest, the understood and the known to the human. It is in what it is and how it is, in reality, in simply being given, in content, resource and validity ${ }^{(17)}$.

To designate an entity or a person who owns this being, Heidegger uses the word Dasein. Dasein is an entity that, being, reveals the being from its existential condition, the entity to which the being shows itself; this understanding occurs in the midst of other entities with which it relates. It refers to the entity that we ourselves are and whose being is each time, the only entity to have a sense capable of creating, desiring, deconstructing and everything else that demonstrates its totality in the interaction with its own existence ${ }^{(17)}$.

Therefore, Dasein presents an existential structure in which it is inserted in the world, established by projects, located in time and space, involved in the relationship with others and with objects, because Heidegger rejects understanding the human being as an isolated unit, where there is being necessarily there is entity. Therefore, being is being-in-the-world and also being-in-the-world-with-others ${ }^{(19-20)}$.

When understanding the meaning of Dasein as an existential totality, one should know that its understanding of itself will depend on its existence and the possibility of being or not itself, which will allow it to show itself in its authenticity and/or inauthenticity. These ways-of-being "are based on the fact that Dasein is generally determined by being-every-time-mine"(17).

Authenticity is a way of being, of existing to the various possibilities. Inauthenticity is characterized as an inauthentic way of being, a sphere of existence that goes without its own direction, but does not mean anything less or a lower degree of being, being able to determine Dasein according to its achievements in its occupations and interests ${ }^{(17)}$.

But what do we seek to reveal in Dasein? What is always revealed in its relative unveiling is something of its own; therefore, the truth is the world unveiling itself for each being. It is the unveiled facets that enable a unique understanding of the phenomenon, providing new questions about $\mathrm{it}^{(21)}$.

\section{METHODS}

\section{Ethical aspects}

This study was approved by the Board of Nursing of the Pediatric Nursing Service of the hospital where the study was conducted and by the Research Ethics Committee of Universidade Estadual de Campinas (UNICAMP), in 2017. Participants signed the Informed Consent Form (ICF) in two copies. To guarantee anonymity, participants were identified by fictitious names. 
Ethical aspects have been respected for research involving human beings recommended by Resolution CNS (Conselho Nacional de Saúde - Brazilian National Health Council)/MoH 466/12 of the Brazilian National Commission for Ethics in Research (CONEP Comissão Nacional de Ética em Pesquisa) ${ }^{(22)}$.

\section{Type of study}

This is a qualitative research with a phenomenological approach. Phenomenology is seen as a philosophical method of authentic thinking, capable of allowing things to present themselves in their own reality, without projecting any conventional interpretive category related to other phenomena, seeking to establish a new perspective to see things as they appear ${ }^{(23)}$.

This study focuses on the experiences of relatives of children before bad news report in Pediatric Intensive Care Unit (PICU). Therefore, this approach was chosen due to the fact that it provides the unveiling of the lived senses, in an attitude of involvement with the world of experience, involving the apparent and the invisible ${ }^{(21)}$.

In this perspective, subjects of experience are launched into the world as a historical horizon of meanings, so that it is the world that makes it possible for something to show itself through phenomenological experience. The essence of man lies in his existence and it is only through the being's existence that it is possible to address being in order to unveil its mysteries ${ }^{(17)}$.

This investigation was conducted and structured with reference to Consolidation Criteria for Reporting Qualitative Studies $(\text { COREQ) })^{(24)}$.

\section{Methodological procedures}

Considering that research involving people's lived experiences refers to a medium that allows their narration, interviews were a methodological resource used to access the world of relatives of seriously ill children. Phenomenological interview is an existential approach that seeks, above all the subjects' authentic speech, that silence that breaks and expresses, in the report, something probably never said or reflected, which is the experience of those who are experiencing it and assigning meanings ${ }^{(25)}$.

The phenomenological interviews were carried out by the main researcher, in a quiet place, outside PICU, guided by the following questions: during your child's hospitalization in ICU, have you ever experienced news that you considered difficult? What happened to you/your family after that news?

\section{Study setting}

The study was carried out at a Pediatric Nursing service of a public teaching hospital located in the countryside of the state of São Paulo, which provides assistance to children with acute and chronic diseases, in clinical and/or surgical conditions, as well as their relatives.

\section{Data source}

Seventeen relatives were invited to participate in the survey, but two refused for personal reasons. To access the participants, the choice for convenience was used, based on the search for those who were more accessible, collaborative and available to participate in the study ${ }^{(26)}$.

Thus, participants were 15 relatives of children hospitalized in PICU. Relatives accompanying children during hospitalization in PICU, who experienced bad news according to their own perspective and over 18 years old have been included.

The family concept was adopted for Family Centered Care: family is who its members say they are ${ }^{(27)}$, a group of individuals linked by strong emotional bonds, durability and inclination to participate in each other's lives. We present the main characteristics of participants in Chart 1.

Chart 1 - Characteristics of participants, Campinas, São Paulo, Brazil, 2018-2019

\begin{tabular}{|c|c|c|c|c|c|c|}
\hline Name & Age & Kinship & Child's age & $\begin{array}{c}\text { Reason for } \\
\text { hospitalization }\end{array}$ & $\begin{array}{l}\text { Number of hospitalizations in } \\
\text { Pediatric Intensive Care Unit }\end{array}$ & $\begin{array}{l}\text { Days of hospitalization on } \\
\text { the date of the interview }\end{array}$ \\
\hline 1. Roberta & 52 & Grandmother & 9 months & Digestive surgery & First & 2 months \\
\hline 2. Keila & 40 & Grandmother & 2 years & Polytrauma & First & 19 days \\
\hline 3. Sandra & 21 & Mother & 2 years & Polytrauma & First & 1 month \\
\hline 4. Carla & 41 & Mother & 1year & Myoclonus & First & 1 month \\
\hline 5. Bianca & 51 & Grandmother & 1 year & Drowning & First & 16 days \\
\hline 6. Almira & 22 & Mother & 4 months & Cardiac surgery & First & 21 days \\
\hline 7. Ivina & 26 & Mother & 3 months & Biliary Atresia & Second & 15 days \\
\hline 8. Amanda & 42 & Mother & 6 months & Cardiac surgery & First & 2 months \\
\hline 9. Alba & 31 & Mother & 2 months & Meningitis & First & 15 days \\
\hline 10. João & 32 & Father & 2 months & Cardiac surgery & First & 8 days \\
\hline 11. Dora & 19 & Mother & 3 months & Meningitis & Second & 1 month \\
\hline 12. George & 34 & Father & 5 months & Meningitis & Second & 5 days \\
\hline 13. Álvaro & 42 & Father & 7 months & Biliary Atresia & Second & 10 days \\
\hline 14. Aline & 28 & Aunt & 4 months & Metabolic syndrome & First & 5 days \\
\hline 15. Gisele & 36 & Mother & 4 months & Hydrocephalus & Second & 2 months \\
\hline
\end{tabular}




\section{Data collection and organization}

The interviews were carried out from October 2018 to March 2019. During the period of the study, a plan was established to be at PICU twice a week and in different shifts, with the objective of the main author becoming familiar with service's routine, be recognized by health professionals as a researcher and approach relatives of hospitalized children.

In this perspective, when approaching the family, the researcher introduced herself as a research nurse, starting the dialogue; at another time, she talked about the study's theme, briefly explaining the research objective.

The interviews lasted an average of 17 minutes and were recorded, with consent of participants, on a digital recorder; later, they were transcribed in full, being closed when the speeches obtained reached theoretical saturation, i.e., when interviews showed consistency from a continuous process of discourse analysis according to the researcher ${ }^{(28)}$.

It is worth mentioning that the main researcher appropriated the phenomenological attitude that includes the interview during a specific discipline for this purpose.

\section{Methodological framework and discourse analysis}

In order to apprehend the essence of a phenomenon, through relatives' speeches, it was decided to analyze the situated phenomenon's structure, which follows ${ }^{(29)}$ : speech's content reading, in order to apprehend its global configuration; attentive rereading, in order to identify the significant statements (units of meanings); search for convergences (elements that are common to several speeches) and divergences (elements that are peculiar to only one speech or a few); from the convergences/ divergences, elaboration of ontological categories; phenomenological understanding based on Heidegger's conceptions, through Being and Time ${ }^{(17)}$.

\section{RESULTS}

From the attentive listening to relatives' speeches of critically ill children, before bad news report in PICU, starting from the experiences that involve them, it was possible to apprehend some facets related to receiving bad news.

Based on the units of meaning derived from the speeches, the results were organized into ontological categories, which will be presented and discussed below, in the light of some Heideggerian concepts, as well as authors who address the theme.

\section{Coping of relatives before bad news: from despair to fear of the possibility of death}

The being-family-of-a-hospitalized-child-in-PICU, in its existence, experiences the facticity of being released in unpredictable situations. Regardless of their choices, the bad news surprises them by causing feelings like shock, despair and fear.

The initial impact was associated with the hostile environment, even though it was considered sacred, because it deals with life and death situations, not only with its own experience, but also with the experience of the suffering of other children/relatives who are hospitalized in PICU.

Ah, it was hard to know that she was in the ICU, because in the ICU there are always the most serious cases. [...] she was intubated, she is premature and can't take it. It is already the 4th surgery that my girl undergoes and every time she goes to the ICU. (Dora)

ICU is a very sacred place, a place that deals with life and death. But experiencing both here is very hard. Every family, every person inside [...]. (Bianca)

The feelings of shock are related to the unknown technology, the continuous performance of therapeutic procedures and the flow of health professionals in handling a child, causing discomfort and pain when talking about this experience.

So, the bad news concerning ICU hospitalization is difficult to talk about, because we learn to cope and we even know the machines, without ever having studied. Even a machine whistle lets us down. So, it's a situation that I don't like to talk about, I wouldn't like to be talking, because it is very difficult to experience. I just hope I don't have to spend more. Every entrance of a doctor, every entrance of a nurse, every medication on a patient, not only mine, but any child, hurts the soul and the heart. (Bianca)

[...] new exams are performed every day, everything is like that ... every day it's new, so we try to calm down as much as we can and try to understand, but it's hard, we don't have much to say; there are days when we cry, there are days when we get more upset, there are days that are better, but it is what it is, since her hospitalization has been like this. There are days when we are better, there are days when we are worse, the news comes, but there is not much to be said. It is really a complicated, difficult moment, because we adjust ourselves daily. (Ivina)

Faced with the condition of severity, upon realizing the delay in restoring the child's health, the relative is increasingly exposed to suffering, being surprised by the news about clinical instability.

And here comes the process of being well, because he hasn't been there for days. Oh, and every day I think we get a surprise. He's been there for two months now; in those two months, he already had, as I told you, he had four cardiac arrests. So, we get discouraged, because you are praying, talking to God and then there are days when you come here and go away devastated. [gets emotional] it's hard! (Amanda)

There was a day when I got here and then the doctor explained why she had difficulty breathing, then she had to increase the machine's level. Then I said "oh my God, instead of this machine decreasing, is it increasing?" The doctor told me that she was stopping breathing, what was doing her breathing was the machine and that her brain was pausing. It was all crazy, you know? [...] so, it wasn't easy, every day you have to wait for good news, bad news, that's it. (Alba)

[...] / am, we are trying here, and my grandson is still in the ICU. There is still no prediction of when he will leave. [pause] just yesterday the doctor told us that his condition is still very worrying. [Eyes full of tears and shaking hands]. (Roberta) 
Throughout hospitalization, relatives' feelings intensify before their children's seriousness, which does not recover as expected.

Seeing a child in bed is not easy. We feel useless, because you can't do anything. You see it there and you can't do it... you can't have any reaction for it. You just have to sit and watch. Ah, it's difficult. (Amanda)

But that's it, it's very desperate, because you don't know how to help, or where to, to know if what's being done is right. (Aline)

Among these feelings, fear of the possibility of death emerges as a common aspect for all relatives. Thus, the issue of death is considered as fearful, especially when the medical team exposes the reality about the child's clinical prognosis and clarifies the risk of death.

Yesterday I went into despair, because they started to bathe him, so / suggested that I sit him in the basin, to see if he started to move his body, because he was very hard! We took him; the moment I took his arm, he started to cry. [pause] then I said to her "let's sit him in the basin, so we can start to bathe him, because that's how he used to bathe before". Before yesterday it went very well, only yesterday, the blood saturation, heart beat, his pressure dropped, then he had a. The doctor told me it was an increase in heart pressure. The heart almost stopped, went to 40 . Then I went into despair again! I started to cry, I cried a lot out here, because I was afraid of losing him. [...] my fear of losing my grandson is above me! [pause crying]. (Roberta)

It was a very difficult word, to know that we could lose him at any moment. (Keila)

Look, this news is not easy for relatives, especially for parents. Because, by the time the doctor arrived and said that everything that had to be done on the part of the medical team had already been done and only depended on her reaction, it was a moment of despair. I think that any father is in despair [...]. (Álvaro)

[...] when she was putting the access in him, his pressure dropped and he had cardiac arrest. Wow, that to me something that looked like he was going to die. (Sandra)

However, even before despair experienced in these stressful situations, especially those that mark the possibility of death, the relative seeks explanations to understand the child's situation.

\section{Coping of relatives before bad news: from initial impact to hope}

The being-family-of-a-hospitalized-child-in-PICU considers hope as a feeling that helps the family to fight, every day, in face of turbulent situations, aiming for victory.

[...] grow one more chance of hope, one hope, one chance of victory. [emotional pause] This is what my wife and I are doing, we are uniting more and more to be in the fight. [...] It is not easy, it is not being easy, but we will overcome all obstacles. (Álvaro)

[...] but in the case involving ... again my daughter, she lights up another expectation for us. (George)
[...] but the hope continues, the prayers and everything. God is also very important and has given us a lot of strength, believing is what has helped us, given us strength for all this. (Ivina)

In this context, the relative, even though he/she understands the risk of death announced by the medical team, does not accept this fact, revealing that hope remains. Thus, it projects itself into its existence and states that there is an internal energy capable of comforting it.

So, many people even in medicine were not believing so much. So, people were always saying, "oh, butyou know that doctors always say it got better, but there is still a risk, she is at risk of dying, and all". Until the third day, we had to hear it from the doctors. Are they wrong? No. They are passing the reality, but we had such great energy inside us saying that it was okay that we were more relaxed. (João)

Amid the circumstances, the relative sees a greater strength, often revealed by the valorization of faith and belief in the divine. Before the Creator, he puts himself in the position of surrender and confidence in the child's future.

Hoping that at any time, God ... [lowers her head and cries] put my baby back in my arms and speak to go away, because he is fine. [pause looking straight into my eyes]. (Roberta)

We get attached to us and our faith. (Aline)

And I know that the Lord is also with us in this battle. [lowers his head and cries] [...] God willing, we will achieve this victory. I have faith in God that we will get. [pause]. (Álvaro)

The faith of other relatives, who are far from the situation, is support for those who accompany their children during hospitalization, helping to cope with adversity.

[...] when they receive the news, they say "oh, it will work, whatever God wants, he will be fine, soon he will get out of there". (Almira)

[...] my mother only replied that faith moves mountains. She answered and she is from an evangelical family, my whole family is very evangelical. (Alba)

In addition to faith in the divine, the relative places hope in health professionals, believing in the technical skills to help restore the child's health.

But then I said "no, we believe in doctors and what doctors say". (Carla)

Then one day I arrived and said, "look, doctor, the only thing I don't want is that you give up on my daughter. Do everything you can! Even though I know she is at risk, do everything you can". (Gisele)

Finally, in addition to the relative having a belief in the divine and believing that medical conduct will work, he also trusts the reaction of children who fights for life.

But it was not so difficult, because after the surgery we have such a great faith in God that nothing can bring us down. We just look at 
her, we only see her strength. For us, she is being an example, she is a warrior that we are seeing what it is really like to fight for life. So, that's why it wasn't that frustrated. I say it is the most difficult news. By the faith that we have in God, then we don't... (João)

I don't have much to say, what I have to say is that we have to be very attached to God. Because even the doctors already said that what everything had to be done, they already did; now they are waiting for her reaction now. So ... she is doing her part, we are doing our part. I have faith in God, that He will help us. So, that's what I have to say [emotional pause]. (Álvaro)

\section{DISCUSSION}

To understand the experiences of relatives before bad news report in PICU, it is necessary to know their ways of being-in-theworld. Heidegger defines being-in-the-world as the human being; Dasein is about the man launched into a world that inhabits him and is also capable of questioning his own reality and himself ${ }^{(30)}$.

Being-in-the-world, Dasein is always being-with-the-other, relating within a context of average practices and understandings already pre-established ${ }^{(31)}$. In this context, the world is PICU and the relatives of hospitalized children who, in this scenario, are in the world with health professionals and other relatives who experience bad news.

The relatives of children hospitalized in PICUs are revealed according to their ways of existing, i.e., their ways-of-being-in-theworld when experiencing unpredictable situations, such as the length of indefinite hospital stay, and are launched in the facticity in which they have no control and which they did not choose.

Parents, experiencing their son's disease, revealed agony before the uncertainty of the future, as if an unwanted presence suddenly knocked on their door ${ }^{(32)}$. In addition to this distress, relatives of children undergoing cancer treatment reported bad news about their child's situation as "feeling lost"(33), determining changes in their daily lives overnight. Thus, being-family-of-a-hospitalizedchild-in-PICU, immersed in the facticity of experiencing the unknown, impels their action and reflect on the bad news. In the face of uncertainties and afflictions, relatives unveil unique ways of being permeated by feelings, such as shock and despair.

Dasein in-a-world-at-PICU is engaged in a daily deal, in the relations with the intramundane entities that come to meet them, facing unknown high-tech devices, with the continuous performance of therapeutic procedures and with a large flow of health professionals in handling children ${ }^{(34)}$. Therefore, Dasein discovers the entities that come to meet ${ }^{(17)}$.

Heidegger, when analyzing the being of objects in the surrounding world, an environment that encompasses entities in their entirety, points out the way they are arranged, i.e., spatiality. These entities that come to meet being are spatial; however, they do not occupy a geometric space in dimensions, but rather a qualitative space, expressed by the meanings they represent. It is in everyday occupations that Dasein is spatialized and the entities themselves have their spatiality ${ }^{(17)}$.

Therefore, the relatives launched in the surrounding world are surprised and revealed to be limited and powerless before their facticity, for not noticing the improvement of children, as expected. Moreover, fear emerges in the daily life of the
being-family-of-a-hospitalized-child-in-PICU with the real information described by the medical team that includes the possibility of death.

As a mode of disposition, the fear phenomenon is feeling fearful, not as feeling, but as an existential mode of Dasein, which is approached by Heidegger in three points of view ${ }^{(17)}$ : what is feared or death; the fear, disposition of Dasein; for which one fears, the possibility of death. Thus, when the doctor exposes the possibility of death to relatives, it is considered a fearful event. Therefore, the one who defines the character of menacing to the fearful is Dasein who fears. Discourses reveal fright ${ }^{(17)}$ with the news of the possibility of death, because even if it did not happen, at any moment it can suddenly end the existence of the busy being-in-the-world.

The issue of finitude is revealed, for the family, as something imminent and inverse to the chronological order of life, an uncomfortable issue that will trigger the rupture of the life-world of all people involved in this process ${ }^{(35)}$. The possibility of the death of a child is considered inexplicable and immeasurable ${ }^{(36)}$. Therefore, "everyday life urges on the urgency of occupation and on getting rid of the bonds of tiring and passive thinking about death"(17).

Relatives, in their existence, are marked by relationships with themselves and with the world and, consequently, define them according to their own possibilities of being in accordance with what the world offers them. Dasein has the freedom to take responsibility for being itself and to decide to be in the world in an authentic or inauthentic way ${ }^{(20)}$.

Thus, the time and space in which Dasein's relations take place reveal ways-of-being-in-the-world, always in movement of concealment and unveiling. The possibilities of being in a world are anchored in its ontological structure, the opening of the horizon possible to choose, project and reject ${ }^{(17)}$. Therefore, the fact that being-family-of-a-hospitalized-child-in-PICU reveals itself inauthentically before bad news, when it does not accept the severity of the children's clinical condition and does not cancel the possibility of authenticity, because, in some moment of its existence, Dasein has already understood itself in one way or another.

However, assuming reality is not something static, but dynamic, and when realizing that in face of gravity death is a possibility, relatives hide behind appearances, disguise themselves and collect themselves before the news about children's risk of death, in an improper disposition to avoid being-certain, for not assuming this facticity in their life. In this condition, the self hides hensekf before the possibilities that are open, away from being himself and receiving from the others and his daily occupation, the determinations that he understands $s^{(31,37)}$.

Therefore, being-family-of-a-hospitalized-child-in-PICU is on the run from assuming its authentic being, seeking comfort in impersonality as a coping mechanism and revealing itself in the way of waiting for the future to do something to reverse children's health status.

In this sense, relatives, before bad news announcement, close themselves in a circle that attracts them, i.e., their mobility is like an improper whirlwind, without realizing their own possibilities ${ }^{(17)}$. Thus, he sees hope in something or someone as essential to face the situation; in other words, the search for an ontic hope that 
can veil the real. Thus, for relatives, hope is anchored in the survival of children in any way, regardless of what is said by health professionals and the reality experienced.

A study carried out with grandparents of children hospitalized in PICU also showed, in its results, hope as something that impels the family to envision better days and "seek strength to be able to stabilize the "boat" "(38). Hope, in its ontological essence, is a horizon that unfolds and refers to a category linked to temporality, lived in the present, linked to the past and projected with an appeal to the future. It implies the establishment of significant objectives, revealing itself as a multifaceted, multidimensional phenomenon ${ }^{(39)}$. Hope works as a way of feeling, a way of thinking, behaving and relating to oneself and the world ${ }^{(40)}$. "Hope is not waiting, it is walking, it is always taking a step forward with which everything begins again"(41).

In everyday life, time extends through the present, a succession of "now"(17). In this way, the being-family-of-a-hospitalized-child-in$\mathrm{PICU}$ projects itself into the future that he intends to experience, especially when, in his project, he hides the possibility of children's death; thus, they are supported by ontic perspectives. Studies show that, given the feeling of fear of death, faith is a comfort, a hope ${ }^{(1,4,42)}$. Parents of children diagnosed with cancer revealed that hope is the possible way to achieve goals ${ }^{(43)}$.

Being-a-family-of-a-hospitalized-child-in-PICU seeks to anchor in relationships and interactions with other relatives, expanding hope in the recovery of children's health. Ontically, it intensifies when, when accompanying the children, they perceive something good said by relatives who are physically distant, motivating them to continue fighting for children's lives.

Dasein reveals hope in divine providence by aiming, through faith, for the healing of children. Relatives of children with cancer sought spirituality, emphasized in faith and closeness to God, as support to deal with fear and impotence before the disease's severity ${ }^{(44-45)}$.

Thus, relatives place expectations in relation to health professionals, believing in technical skills to assist in the recovery of children. In addition, even though relatives are informed that all conducts have been carried out and about the risk of death, they maintain the hope that children will react positively to treatment. These are strategies to face the situation, i.e., to avoid the fear of death.

Finally, considering bad news report in PICU, it is possible for relatives to review their existential project, assuming their human condition, adopting an authentic existence and experiencing oneself ${ }^{(17)}$. However, this inauthentic-authentic movement is not so simple, because authenticity is not given as something already pre-established when the being is born, but it is always a possibility to be and not to be in every relationship, at every moment of relatives with the world.

But, how do these modes of existence come about? Heidegger emphasizes that it only happens when Dasein gives in to the ontological appeals and pressures that constitute the way-of-being, mainly understanding itself as being-for-deat $h^{(17)}$. Faced with these calls, Dasein is distressed. The disposition of anguish, in Being and Time, is to be launched into an unselected world, having to make choices; it is in anguish that Dasein frees itself from impersonal existence, opens the possibility and the responsibility to assume its power-being in an authentic way ${ }^{(46)}$.
Therefore, only when the family-being-of-a-hospitalized-childin-PICU, faced with a shared care between the health team and the family, is able to make constant confrontations with their primordial anguish and understand their condition of being-fordeath and exposure to existential facticity, will be able to face the vulnerability presented to him in an authentic way.

\section{Study limitations}

Due to the fact that the choice of participants was made out of convenience ${ }^{(26)}$, speeches reveal the experiences of relatives of critically ill infants and toddlers who, for the most part, reported their experience of PICU hospitalization for the first time. Thus, it is questioned that future studies about the experiences of relatives of children with other age groups and with a history of multiple hospitalizations are relevant, as they also experience bad news, although they are already launched in the disease's world. However, this limitation does not compromise the purpose and originality of this study.

\section{Contributions to nursing}

The results of this study may contribute to reflections on the announcement of bad news and how health teams, and especially nursing, need to extrapolate what has already been given, to understand relatives from the repercussions that such news determines in their daily lives, considering all particularities of each Dasein's existence.

Finally, it is suggested that health professionals working in permanent education of health services prioritize developing skills that encompass the human dimension, going beyond the technical-scientific perspective.

\section{FINAL CONSIDERATIONS}

The study made it possible to understand some facets of the experiences of relatives of seriously ill children before bad news report. Being-family-of-children-hospitalized-in-PICU reveals itself in the contingency of responding to the calls, in some way, in its being-in-the-world. Dasein, although it has not revealed itself in the way of being authentic before bad news, it reveals itself in a singular way, in the inauthentic of everyday life, based on ontic expectations.

Considering the unveiling of this phenomenon, it is believed that, in this process, the solidarity and sensitivity of health professionals, especially nursing professionals, in the existential dimension apprehension of relatives who experience such an experience is essential. Nurses need to understand that relatives have and show themselves in different ways during their existence; it is important to offer these relatives opportunities to project themselves in their uniqueness.

However, this understanding will happen when the health professional confronts his own movement of being, regarding his own existence. Being-in-the-world, marked by finitude in the face of an existence that is also defined by temporality, the choice of an action that surpasses technical knowledge and ways of doing data already delivered. Furthermore, perceiving being-in-the-world-withothers as a possibility of being that can reflect the unthought, a fundamental ontological condition for caring for the other. 


\section{REFERENCES}

1. Kumata CS, Borges AA, Dupas G. Comunicação de más notícias à família da criança hospitalizada. Cienc Cuid Saude. 2015;14(4):1411-18. doi: 10.4025/cienccuidsaude.v14i4.25894

2. Luisada V, Fiamenghi-Jr GA, Carvalho SG, Assis-Madeira EA, Blascovi-Assis SM. Experiências de médicos ao comunicarem o diagnóstico da deficiência de bebês aos pais. Ciência\&Saúde [Internet]. 2015 [cited 2020 Jan 31];8(3):121-128. Available from: http://revistaseletronicas. pucrs.br/ojs/index.php/faenfi/about/

3. Royal College of Nursing. Breaking bad news: supporting parents when they are told of their child's diagnosis. RCN guidance for nurses, midwives and health visitors. London: RCN; 2015. 22 p.

4. Matthews T, Baken D, Ross K, Ogilvie E, Kent L. The experiences of patients and their family members when receiving bad news about cancer: a qualitative meta-synthesis. Psycho-Oncology. 2019;28:2286-2294. doi:10.1002/pon.524

5. Silva RBL. Comunicando notícias difíceis na unidade de terapia intensiva. Arq Catarin Med [Internet]. 2015 [cited 2020 Jan 20];44(1):82-92. Available from: http://www.acm.org.br/acm/seer/index.php/arquivos/article/view/13

6. Monteiro DT, Quintana AM. A comunicação de más notícias na UTI: perspectiva dos médicos. Psic Teor Pesqui. 2016;32(4):1-9. doi:10.1590/0102.3772e324221

7. Beverley A. Reflecting on the communication process in health care. Part 1: clinical practice-breaking bad News. British J Nurs. 2019;28(13):858-63. doi: 10.12968/bjon.2019.28.14.927

8. Franklin JB, Joseph PW, Nicki DV. Delivering bad or life-altering news. Am Fam Physician [Internet]. 2018 [cited 2020 Jan 20];98(2):99-104. Available from: https://www.aafp.org/afp/2018/0715/p99.html

9. Silva DB, Hagemann PMS, Pereira C, Neme CMB. Experiências e sentimentos de mães diante da doença de Moyamoya de seus filhos. Estud Psicol. 2017;34(4):523-33. doi: 10.1590/1982-02752017000400008

10. Paula DPS, Silva GRC, Andrade JMO, Paraiso AF. Câncer infanto juvenil do âmbito familiar: percepções e experiências frente ao diagnóstico. Rev Cuid. 2019;10(1):e570. doi: 10.15649/cuidarte.v10i1.570

11. Vale PRFL, Cerqueira S, Hudson P. Santos Junior HPS, Black BP, Carvalho ESS. Bad news: Families' experiences and feelings surrounding the diagnosis of Zika-related microcephaly. Nurs Inquiry. 2019;26(e12274):1-10. doi:10.1111/nin.12274

12. Karkow MC, Girardon-Perlini NMO, Stamm B, Camponogara S, Terra MG, Viero V. Experience of families facing the revelation of the cancer diagnosis in one of its integrants. Rev Min Enferm [Internet]. 2015 [cited 2019 Feb 10];19(3):741-746. Available from: http://www.reme.org.br/artigo/detalhes/1036

13. Simeone S, Pucciarelli G, Perrone M, Dell Angelo G, Teresa R, Guillari A, et al. The lived experiences of the parentes of children admitted to a paediatric cardiac intensive care unit. Heart Lung. 2018;47:631-637. doi:10.1016/j.hrtlng.2018.08.002

14. Ataide CA, Ricas J. O diagnóstico das crianças com doença falciforme: desafios e perspectivas de enfrentamento. Scientia Plena. 2016;4(2):19-28. doi: 10.14808/sci.plena.2017.059908

15. Davies D, Mack C. When parents say "more" and health care professionals say "enough". Paediatr Child Health. 2015;20(3):135-8. doi: 10.1093/ $\mathrm{pch} / 20.3 .135$

16. Santos F, Guedes AS, Tavares MC, Silva RB, Brandão JM, Santana WB, et al. Vivências de mães com crianças internadas com diagnóstico de câncer. Enferm Actual Costa Rica [Internet]. 2018[cited 2019 Feb 10];34:38-52. Available from: https://www.scielo.sa.cr/pdf/enfermeria/ n34/1409-4568-enfermeria-34-38.pdf

17. Heidegger M. Ser e tempo. Campinas: Unicamp; 2014. 1199 p.

18. Kirchner R. A análise existencial heideggeriana: um modo original de compreender o ser humano. Rev Nufen Phenom Interd [Internet]. 2016 [cited 2018 Jan 15];8(2):112-28. Available from: http://pepsic.bvsalud.org/pdf/rnufen/v8n2/a09.pdf

19. Dettoni LL. Dettoni JL, Dettoni JL. O homem: ser-no-mundo-com-os-outros. Clareira: Rev Filos Reg Amazon [Internet]. 2016 [cited 2018 Jan 15];3(2):102-13. Available from: https://www.periodicos.unir.br/index.php/clareira/article/download/3630/2510

20. Braga TBM, Farinha MG. Heidegger: em busca de sentido para a existência humana. Rev Abordagem Gestált [Internet]. 2017 [cited 2019 Fev 5];23(1):65-73. Available from: http://pepsic.bvsalud.org/scielo.php?script=sci_arttext\&pid=S1809-68672017000100008

21. Cerbone DR. Fenomenologia. Petrópolis: Vozes; 2014. 292 p.

22. Ministério da Saúde (BR). Resolução n. 466/12. Aprova as diretrizes e normas regulamentadoras de pesquisas envolvendo seres humanos e revoga as Resoluções CNS nos. 196/96, 303/2000 e 404/2008 [Internet]. Brasília; 2012 [cited 2019 Aug 30]. Available from: https://bvsms. saude.gov.br/bvs/saudelegis/cns/2013/res0466_12_12_2012.html

23. Siani SR, Correa DA, Casas ALL. Fenomenologia, métodos fenomenológicos e pesquisa empírica: o instigante universo da construção de conhecimento esquadrinhada na experiência de vida. Revista de Administração da UNIMEP. 2016;14(1):193-9. doi:10.15600/1679-5350/rau. v14n1p193-219

24. Tong A, Sainsbury P, Craig J. Consolidated criteria for reporting qualitative research (COREQ): a 32-item checklist for interviews and focus groups. Int J Qual Health Care. 2007;19(6):349-57. doi: 10.1093/intqhc/mzm042 
25. Guerrero-Castañeda RF, Menezes TMO, Ojeda-Vargas MG. Características de la entrevista fenomenológica en investigación en enfermeira. Rev Gaúcha Enferm. 2017;38(2):e67458. doi: 10.1590/1983- 1447.2017.02.67458

26. Freitag RMK. Amostras sociolinguísticas: probabilísticas ou por conveniência? Rev Estudos Lingua(gem) [Internet]. 2018 [cited 2019 Feb 25];26(2):667-86. Available from: http://www.periodicos.letras.ufmg.br/index.php/relin/article/view/12412

27. Wright LM, Leahey M. Enfermeiras e famílias: um guia para avaliação e intervenção na família. 5a ed. São Paulo: Roca; 2012.365 p.

28. Van Rijnsoever FJ. I can't get no saturation: a simulation and guidelines for sample sizes in qualitative research. Plos One. 2017;12(7):e0181689. doi: 10.1371/journal.pone.0181689

29. Martins J, Bicudo MAV. Pesquisa qualitativa em psicologia: fundamentos e recursos básicos. São Paulo: Centauro; 2005.110 p.

30. Cardinalli IE. Heidegger: o estudo dos fenômenos humanos baseados na existência humana como ser-aí (Dasein). Psicol USP [Internet]. 2015 [cited 2019 Jan 10];26(2):249-58. Available from: http://www.scielo.br/pdf/pusp/v26n2/0103-6564-pusp-26-02-00249.pdf

31. Felix W. A ontologia mortal de Martin Heidegger. Nat Hum [Internet]. 2017 [cited 2019 Feb 10];19(2):95-113. Available from: http://pepsic. bvsalud.org/scielo.php?script=sci_arttext\&pid=\$1517-24302017000200006

32. Benedetti GMS, Garanhani ML, Sales CA. The treatment of childhood cancer: unveiling the experience of parents. Rev Latino-Am Enfermagem. 2014;22(3):425-31. doi:10.1590/0104-1169.3264.2433

33. Afonso SBC, Minayo CS. Relationships between oncohematopediatrics, mothers and children in communicating bad news. Ciênc Saúde Coletiva [Internet]. 2017 [cited 2019 Feb 115];22(1):53-62. Available from: http://www.scielo.br/pdf/csc/v22n1/en_1413-8123csc-22-01-0053.pdf

34. Dahav $P$, Sjöström-Strand A. Parents' experiences of their child being admitted to a paediatric intensive care unit: a qualitative study like being in another world. Scand J Caring Sci. 2018;32:363-370. doi:10.1111/scs.12470

35. Carter B, McGoldrick M. As mudanças no ciclo de vida familiar. Porto Alegre: Artes Médicas; 2005. 512 p.

36. Alves KMC, Comassetto I, Almeida TG, Trezza MCSF, Silva JMO, Magalhães APN. The experience of parents of children with cancer in treatment failure conditions. Texto Contexto Enferm [Internet]. 2016 [cited 2019 Jan 15];25(2):e2120014. Available from: http://www.scielo. br/pdf/tce/v25n2/0104-0707-tce-25-02-2120014.pdf

37. Ericksen L. Autenticidade e insolência perante a impessoalidade; um estudo heideggeriano. Aufklärung. 2018;5(1);77-88. doi:10.18012/ arf.2016.37207

38. Moraes ES, Mendes-Castillo AMC. The experience of grandparents of children hospitalized in Pediatric Intensive Care Unit. Rev Esc Enferm USP [Internet]. 2018 [cited 2019 Jan 22];52:e03395. Available from: http://www.scielo.br/pdf/reeusp/v52/en_1980-220X-reeusp-52-e03395.pdf.

39. Querido A. A esperança como foco de enfermagem de saúde mental. Rev Port Enferm Saúde Mental [Internet]. 2018 [cited 2019 Jan 10];6:68. Available from: http://www.scielo.mec.pt/pdf/rpesm/nspe6/nspe6a01.pdf

40. Walley J. Temple MD, FRCSC, FACS. Inspiring hope: a physician' responsibility, translating the science into clinical practice. J Surg Oncol. 2018;117:545-550. doi: 10.1002/jso.24887

41. Rocha Z. Esperança não é esperar, é caminhar. Reflexões filosóficas sobre a esperança e suas ressonâncias na teoria e clínica psicanalíticas. Rev Latinoam Psicopat Fund. 2007;10(2):255-73. doi: 10.1590/1415-47142007002005

42. Alves DA, Silva LG, Delmondes GA, Lemos ICS, Kerntopf MR, Albuquerque GA. Cuidador de criança com câncer: religiosidade e espiritualidade como mecanismos de enfrentamento. Rev Cuid. 2016;7(2):1318-24. doi: 10.15649/cuidarte.v7i2.336

43. Popp JM, Conway M, Pantaleão A. Parents'Experience With Their Child's Cancer Diagnosis: Do Hopefulness, Family Functioning, and Perceptions of Care Matter? J Pediatric Oncol Nurs. 2015;32(4):253-260. doi: 10.1177/1043454214563404

44. Nicholas D, Barrera M, Granek L, D'Agostino NM, Shaheed J, Beaune L, et al. Parental spirituality in life-threatening pediatric cancer. J Psychosoc Oncol. 2017;35:323-34. doi: 10.1080/07347332.2017.1292573

45. Myrna AA, Doumita AC, Saabb R, Majdalanib M. Spirituality among parents of children with cancer in a Middle Eastern Country. European J Oncol Nurs. 2019;39:21-27. doi: 10.1016/j.ejon.2018.12.009

46. Jesus ACG. Heidegger e o fim da metafísica. Ideação [Internet]. 2018 [cited 2019 Feb 15];38:73-97. Available from: http://periodicos.uefs.br/ ojs/index.php/revistaideacao/article/view/4285/3508 